\title{
Idiopathic Hypertrophic Pachymeningitis Manifesting with Frontal Brain Edema
}

\author{
Paquimeningite Hipertrófica Idiopática Manifestando-se com Edema Cerebral Frontal
}

\section{Mário Emílio Teixeira Dourado Júnior' ${ }^{1}$ Ricardo Humberto de Miranda Félix², Marcos Dias Leâo ${ }^{3}$}

\begin{abstract}
Introduction. Hypertrophic pachymeningitis (HP) is a rare inflammatory disease that results in thickening of the dura mater. Atypically, it can progress to include the involvement of the cerebral parenchyma. Method. In this paper, we report the rare case of a 31-year-old man with a three-week history of headaches, seizures, impairments of cognitive function, and changes in behavior and mood. Magnetic resonance imaging (MRI) of the brain showed a thickening and an abnormal enhancement of the dura mater over the falx cerebri with extensions into the adjacent cranial base and with brain edemas in the frontal lobes. Histopathological study of meningeal and brain biopsies showed an inflammatory process that was compatible with HP. The results of an extensive laboratory investigation were unremarkable and did not provide additional information on the cause of the meningeal disease. The patient exhibited relapses despite immunosuppressive therapy. Conclusion. This case shows the challenges associated with the management of the disease and the importance of early diagnosis to avoid worsening of the condition and cerebral damage.
\end{abstract}

Keywords. Brain Edema, Hypertrophic Pachymeningits, Idiopathic, Treatment.

Citation. Dourado Júnior MET, Félix RHM, Leão MD. Idiopathic Hypertrophic Pachymeningitis Manifesting with Frontal Brain Edema.

\section{RESUMO}

Introduçáo. Paquimeningite Hipertrófica $(\mathrm{PH})$ é uma rara doença inflamatória devido ao espessamento da dura mater. Atipicamente, esta pode progredir com envolvimento do parênquima cerebral. Método. Relatamos um caso raro de um homem de 31 anos com história de três semanas de cefaléia, convulsões, alteração de funções cognitivas, apresentando mudança de comportamento e humor. Ressonância magnética (RNM) do cérebro mostrou espessamento e anormal realce da dura mater sobre a falci cerebral com extensóes para base do crânio e edema cerebral em lobos frontais. Estudo histopatológico após biópsia meníngea e cerebral mostraram um processo inflamatório compatível com $\mathrm{PH}$. Os resultados de extensiva investigaçáo laboratorial não mostraram alterações e não permitiram informação adicional à causa da doença meníngea. $\mathrm{O}$ paciente evoluiu com recaídas, apesar de terapia imunossupressiva. Conclusáo. Esse caso mostra os desafios associados ao manejo da doença e a importância do diagnóstico precoce para evitar piora da doença e dano cerebral.

Unitermos. Edema Encefálico, Paquimeningite Hipertrófica, Idiopático, Tratamento.

Citação. Dourado Júnior MET, Félix RHM, Leão MD. Paquimeningite Hipertrófica Idiopática Manifestando-se com Edema Cerebral Frontal.
Trabalho realizado na Universidade Federal do Rio Grande do Norte UFRN, Natal-RN, Brasil.

1. Neurologista, Doutorando em Neurociências pela Universidade Federal do Rio Grande do Norte (UFRN), Natal-RN, Brasil.

2. Graduando em Medicina da UFRN, Natal-RN, Brasil.

3. Hematologista, Doutor, Professor Titular da disciplina de Doenças do Sistema Linfohematopoético da UFRN, Natal-RN, Brasil.
Endereço para correspondência: Mario Emílio T Dourado Jr Rua Dep Marcílio Furtado, 2042 CEP 59063-360, Natal-RN, Brasil. Tel.: 84 3206-5181

E-mail: medourado@ufrnet.br

Relato de Caso Recebido em: 19/01/10

Aceito em: 16/09/10

Conflito de interesses: não 


\section{INTRODUCTION}

Hypertrophic pachymeningitis (HP) is a rare chronic inflammatory disease that causes thickening of the dura mater with multiple etiologies ${ }^{1}$. If the evaluation of the patient does not reveal a cause for this disease, idiopathic hypertrophic pachymeningitis (IHP) is considered. Headaches and multiple cranial nerve palsies, specifically those of the optic nerve, are the most common symptoms ${ }^{2}$. HP can progress in an unusual manner and can compromise the cerebral parenchyma, manifesting with tremors, ataxia, memory loss, hemiparesis, and seizures ${ }^{1}$.

Cerebral edema with mass effect is very uncommon and was first described by Kadoya ${ }^{3}$. The purpose of this study is to report a rare case of IHP that affected the frontal lobes and caused mass effect in a 31-year-old man.

\section{Case Report}

A 31-year-old man presented in October 2001 with a three-week history of bilateral severe frontal headaches, seizures, impairments of cognitive function, and changes in behavior and mood. Computed tomography (CT) of the brain revealed extensive diffuse edemas in the prefrontal lobes. An MRI of the brain showed a thickening and an abnormal enhancement of the dura mater over the falx cerebri with extensions into the adjacent cranial base. Signal abnormality involving the frontal lobes was compatible with brain edema (Fig 1A to C).

Meningeal and brain biopsies were performed with histopathological findings and showed an inflammatory process with lymphomononuclear cell infiltration and a thickening of the dura mater that was characterized by a dense hypocellular fibrous tissue; the brain tissue had an inflammatory cell infiltration in the Virchow-Robin spaces. Necrotizing vasculitis, noncaseous epithelioid granulomas, and infectious agents were not observed.

The results of extensive laboratory investigations were unremarkable and did not provide addition information on the cause of the meningeal enhancement. Serological tests, including those for HIV, VDRL, Lyme titer, antinuclear antibodies, rheumatoid factors, P- and C-antineutrophil cytoplasmic antibodies, antiphospholipid antibodies, and Ro and La antibodies, were negative. Serum electrophoresis and angiotensin-converting enzyme levels were within normal range. The erythrocyte sedimentation rate was $10 \mathrm{~mm} /$ hour. The chest CT and radiographs were normal. The CSF contained 8 leukocyte/mm3 (65\% lymphocytes), $48 \mathrm{mg} / \mathrm{dl}$ protein, 78 $\mathrm{mg} / \mathrm{dl}$ glucose, and $731 \mathrm{mg} / \mathrm{dl}$ chlorides. Test results for schistosomiasis, toxoplasmosis, brucellosis, cytomegalovirus, and cisticercosis were negative. The results of the CSF analyses for VDRL and HTLV, cultures for bacteria, fungi, parasites, and tubercle bacillus, and cytology for carcinomatous cells were also negative. The patient received prednisone, $60 \mathrm{mg} /$ day for 3 months, which led to an improvement of the brain edema and a reduction of the dura mater enhancement (Fig 1D).

In June 2003, he developed headaches and vision loss in his right eye due to optic neuropathy. Treatment was started with corticosteroids, followed by cyclophosphamide in monthly doses. The cranial MRI was unchanged, and there was no improvement in his vision.

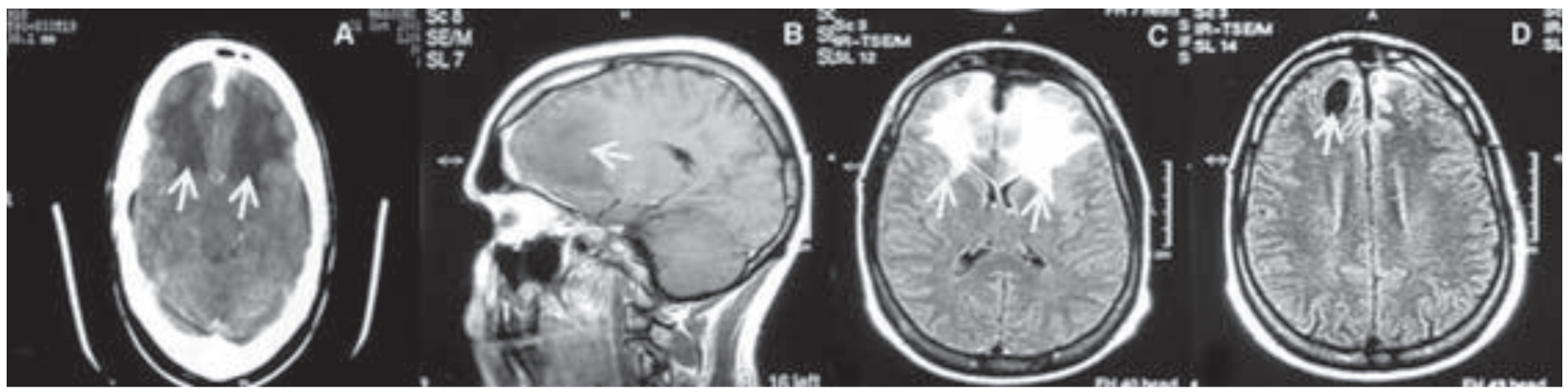

Figure 1. (A) October 2001: Cranial CT showing a bilateral frontal edema. (B) Enhanced sagittal gadolinium showing linear and nodular enhancement of the anterior cranial fossa with a frontal edema. (C) Axial FLAIR showing an edema of the frontal lobes. (D) February 2002: Axial FLAIR showing the resolution of the cerebral edema; cystic lesion in the right frontal region due to cerebral biopsy. 
In November 2003, he showed ptosis in his right eye without ophthalmoplegia. The cranial MRI showed an enhancement in the right cavernous sinus (Fig 2A). He was treated by increasing the dose of prednisone in addition to oral cyclosporine (Fig 2B).

achieved; therefore, anti-CD20 antibody rituximab treatment, $375 \mathrm{mg} / \mathrm{m}^{2}$, was initiated in four cycles. Mild headache relief was reported, and currently, the headaches are controlled with prednisone and symptomatics.

The article was approved by the ethic committee of the Federal University of Rio Grande do Norte (CEP/HUOL: 469/10 e CAAE 0035.0.294.00010).

\section{DISCUSSION}

$\mathrm{HP}$ is a rare inflammatory disease that results in thickening of the dura mater with focal or diffuse involvement of the tentorium and falx cerebri ${ }^{4}$. In 1869, Charcot and Joffrey were the first to describe the medullar version of HP in a patient with syphilis 5 . Naffziger and Stern reported the first cranial variant in $1949^{6}$. The causes of dural thicken-

In 2007, the patient had several episodes of persistent headaches and the cranial MRI showed less enhancement of the dura mater. All laboratory tests were normal and cyclosporine was replaced with methotrexate (20 mg/week). In 2008, he developed a tremor in the right leg, dysarthria, and episodes of seizures. In addition, he developed daily headaches, and his MRI showed a diffuse enhancement of dura (Fig 3A to C). Despite the previous treatments, no significant improvement was ing include tumor, infections, and systemic autoimmune/ vasculitic disorders. Once the most common causes are ruled out, the entity is referred to as idiopathic.

The extension of the inflammatory process to the dura mater from the cerebral parenchyma is rare and manifests with tremors, seizures, ataxia, hemiparesis, or memory loss ${ }^{1}$. A cerebral edema with mass effect is uncommon and is reported by few authors ${ }^{3,4,7-11}$ (Table 1). Diffuse dural enhancement with perifocal edemas can oc-

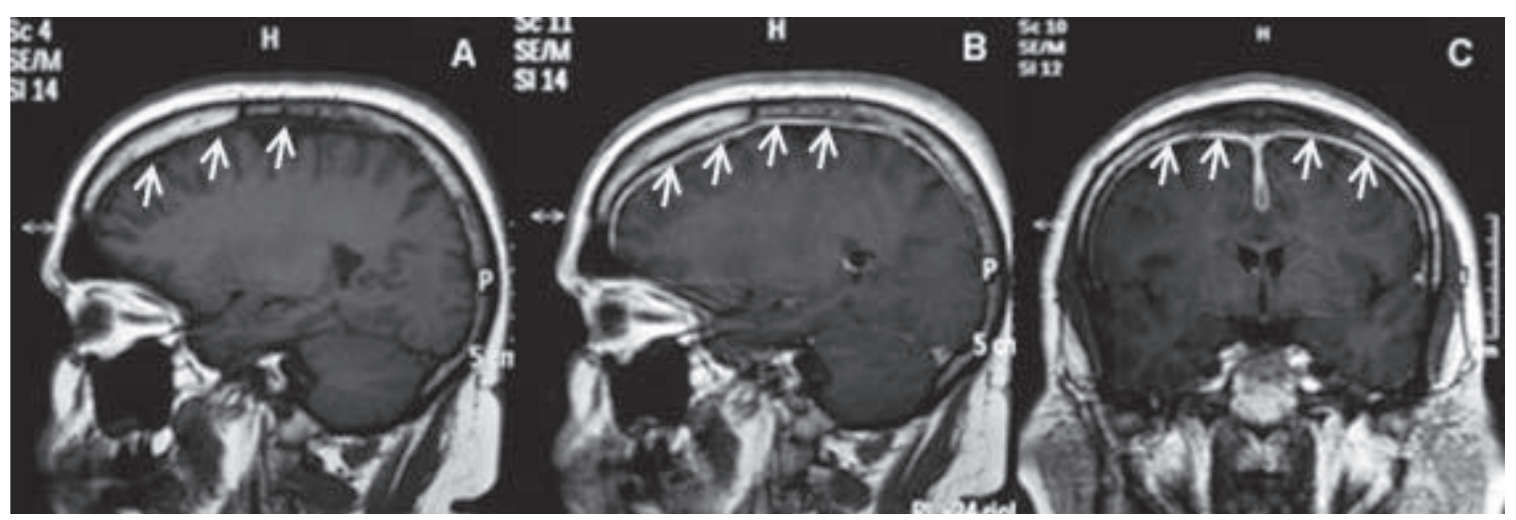

Figure 3. (A) August 2008: Sagittal T1-weighted MRI showing no dural enhancement. (B/C) Sagittal and coronal T1-weighted MRI showing fronto-parietal meningeal enhancement after administration of gadolinium. 
cur in patients with various types of inflammation of the meninges (inflammation due to infections or sarcoidosis following a subdural hemorrhage, inflammation after a craniotomy, meningioma, glioblastoma multiforme, and inflammation from leptomeningeal metastases) ${ }^{7}$. Therefore, a histological examination of dura mater specimens is required to make a definitive diagnosis.

The mechanism of cerebral parenchyma injury is controversial. Venous congestion of the draining sinuses ${ }^{12}$, ischemia caused by compression of the cortical surface by adherent pachymeninges ${ }^{2}$, or inflammatory cells infiltrating the brain parenchyma after invading the subarachnoid and Virchow-Robin spaces ${ }^{3,4}$ are some of the potential mechanisms involved. In our case, the presence of inflammatory cells infiltrating into the Virchow-Robin space is compatible with the latter hypothesis.

Headaches and multiple cranial nerve palsies, specifically those affecting the optic nerve, are the most common symptoms of $\mathrm{IHP}^{1,2}$. This dysfunction is secondary to the thickness of the dura mater in the base of the brain, next to the optic nerve and the cavernous sinus, with consequent nervous compression and ischemic lesions. Therefore, clinical manifestations depend on the location of the abnormal dura lesion and can be observed during an MRI.

The dura mater thickness can be focal or diffuse. An MRI with gadolium is the most accurate imaging modality to evaluate this thickness. The MRI aspect is a hypointense meningeal lesion on T1-weighted slices that enhances with paramagnetic contrast injection. In T2-

Table 1

Reported cases of HP manifesting cerebral edema with mass effect

\begin{tabular}{|c|c|c|c|c|c|c|}
\hline Series & Age & Sex & Clinical features & MRI & Treatment & Follow up \\
\hline $\begin{array}{c}\text { Kadoya et al, } \\
1993^{3}\end{array}$ & 39 & M & $\begin{array}{l}\text { Anosmia, headache, } \\
\text { oculomotor and facial palsy, } \\
\text { hearing disturbance }\end{array}$ & $\begin{array}{l}\text { Thickening of the dura } \\
\text { mater of the cranial base } \\
\text { around the optic canals }\end{array}$ & $\begin{array}{l}\text { Brain Surgery, } \\
\text { steroid therapy }\end{array}$ & $\begin{array}{l}\text { Improvement of } \\
\text { all symptoms }\end{array}$ \\
\hline $\begin{array}{c}\text { Nishizaki et al, } \\
1997^{4}\end{array}$ & 46 & $\mathrm{~F}$ & Seizure & $\begin{array}{c}\text { Thickened dura mater } \\
\text { extending to the left parietal } \\
\text { parenchyma with marked } \\
\text { perifocal edema }\end{array}$ & Brain Surgery & $\begin{array}{l}\text { No neurological } \\
\text { deficits or recurrent } \\
\text { mass for } 10 \text { months }\end{array}$ \\
\hline $\begin{array}{l}\text { Nakazaki et al, } \\
2000^{7}\end{array}$ & 51 & $\mathrm{~F}$ & Headache & $\begin{array}{l}\text { Dural enhancement on } \\
\text { frontotemporal regions with } \\
\text { perifocal edema }\end{array}$ & Prednisolone & $\begin{array}{c}\text { Marked } \\
\text { improvement of the } \\
\text { mass effect }\end{array}$ \\
\hline Lee et al, $2003^{8}$ & 23 & $\mathrm{~F}$ & $\begin{array}{c}\text { Headache, visual } \\
\text { disturbance, delirium, } \\
\text { confusion }\end{array}$ & $\begin{array}{l}\text { Dural thickness and } \\
\text { enhancement of left } \\
\text { and right tentorium }\end{array}$ & $\begin{array}{l}\text { Prednisolone, } \\
\text { brain surgery }\end{array}$ & $\begin{array}{l}\text { Recovery of } \\
\text { symptoms }\end{array}$ \\
\hline $\begin{array}{l}\text { Tuncel et al, } \\
2005^{9}\end{array}$ & 36 & $\mathrm{~F}$ & $\begin{array}{l}\text { Left leg weakness, visual dis- } \\
\text { turbance }\end{array}$ & $\begin{array}{l}\text { Thickness and enhancement } \\
\text { of the dura mater and } \\
\text { perifocal edema in the right } \\
\text { frontoparietal area }\end{array}$ & $\begin{array}{l}\text { Prednisolone, } \\
\text { azathioprine }\end{array}$ & $\begin{array}{l}\text { Improvement of } \\
\text { symptoms }\end{array}$ \\
\hline $\begin{array}{c}\text { Boonyawiroj et } \\
\text { al, } 2004^{10}\end{array}$ & 72 & $\mathrm{~F}$ & $\begin{array}{l}\text { Headache, visual loss, } \\
\text { confusion }\end{array}$ & $\begin{array}{l}\text { Bilateral frontal dural } \\
\text { enhancement with bifrontal } \\
\text { edema }\end{array}$ & Prednisolone & $\begin{array}{l}\text { Headache free, } \\
\text { unchanged } \\
\text { visual loss }\end{array}$ \\
\hline Lu et al, $2008^{11}$ & 43 & M & $\begin{array}{l}\text { Rhythmic abdominal } \\
\text { muscles twitching, seizures }\end{array}$ & $\begin{array}{l}\text { Dural enhancement on } \\
\text { the right parietal region } \\
\text { involving cortical } \\
\text { parenchyma with } \\
\text { perifocal edema }\end{array}$ & $\begin{array}{l}\text { Brain Surgery, } \\
\text { steroid therapy }\end{array}$ & Seizure free \\
\hline
\end{tabular}


weighted imaging, hypo- and hyperintense images can be observed, depending on the degree of fibrosis and of the active inflammatory process. Peripheral enhancement and T2 hyperintensity are common in the early stages of the disease and correspond to inflammatory activity, whereas hypointensity is attributed to fibrosis ${ }^{13}$. The location and pattern of dura mater enhancement is described as linear, nodular, or both. Follow-up MRI evaluations were important to monitor the effect of therapy and showed a reduction of the dura enhancement at the same time as the clinical improvement ${ }^{1}$. Another function of the MRI is to reveal the optimal site for biopsy.

High-dose corticosteroid therapy should be used first, followed by other immunosuppressive agents (azathioprine, cyclophosphamide, cyclosporine, methotrexate, and cloroquine) to control the disease and to reduce the daily dose of steroids ${ }^{1,3}$. Despite the use of corticosteroid therapy, the disease frequently progresses, and the benefit may be temporary and partial ${ }^{1}$. Rituximab is an option when conventional therapy is not sufficient in refractory cases that exhibit a good response, as shown in a Japanese report ${ }^{14}$.

\section{CONCLUSION}

Early diagnosis of IHP is important to avoid worsening of the condition and more permanent cerebral damage, which may occur if IHP is left untreated. This case shows the challenges associated with the management of the disease, with periodic relapses, despite the use of immunosuppressive therapy to achieve clinical improvement.

\section{REFERENCES}

1.Kupersmith MJ, Martin V, Heller G, Shah A, Mitnick HJ. Idiopathic hypertrophic pachymeninigitis. Neurology 2004;62:686-94.

2.Mamelak AN, Kelly WM, Davis RL, Rosenblum ML. Idiopathic hypertrophic cranial pachymeningitis. Report of three cases. J Neurosurg. 1993;79:270-6. http://dx.doi.org/10.3171/jns.1993.79.2.0270

3.Kadoya C, Soejima T, Yamada H, Yokota A. Pachymeningoencephalitis: Case Report. Neurosurgery 1993;33:131-5.

http://dx.doi.org/10.1227/00006123-199307000-00021

4.Nishizaki T, Iwamoto F, Uesugi S, Akimura T, Yamashita K, Ito H. Idiopathic cranial pachymeningoencephalitis focally affecting the parietal dura mater and adjacent brain parenchyma: Case Report. Neurosurgery 1997;40:840-3.

5.Charcot JM, Joffroy A. Deux cas d'atrophie musculaire progressive avec lesions de la substance grise et des faisceaux anterolateraux de le moelle epiniere. Arch Physiol Norm Pathol. 1869;2:354-67.

6.Naffziger HC, Stern WE. Chronic Pachymeningitis: report of a case and review of the literature. Arch Neurol Psychiatry 1949;62:383-411.

7.Nakazaki H, Tanaka T, Isoshima A, Hida T, Nakajima M, Abe T. Idiopathic hypertrophic cranial pachymeningitis with perifocal brain edema: case report. Neurol Med Chir. 2000;40:239-43.

http://dx.doi.org/10.2176/nmc.40.239

8.Lee YC, Chueng YC, Hsu SW, Lui CC. Idiopathic hypertrophic cranial pachymeningitis: case report with 7 years of imaging follow-up. Am J Neuroradiol. 2003;24:119-23.

9.Tuncel D, Yücesan C, Erden E, Savas A, Erden I, Mutluer N. Idiopathic hypertrophic cranial pachymeningitis with perifocal brain edema. Clin Neurol Neurosurg. 2005;107:249-52.

http://dx.doi.org/10.1016/j.clineuro.2004.06.008

10.Boonyawiroj S, Phanthumchinda K. Extensive anterior cranial fossa idiopathic hypertrophic pachymeningitis: a case report and review of the literature. J Med Assoc Thai. 2005;88:1934-40.

11.Lu YR, Yeh JH, Tsai MD, Lee CC, Chen WH. Focal idiopathic hypertrophic pachymeningoencephalitis. J Formos Med Assoc 2008;107:181-4.

http://dx.doi.org/10.1016/S0929-6646(08)60132-1

12. Masson C, Henin D, Hauw JJ, Rey A, Raverdy P, Masson M. Cranial pachymeningitis of unknown origin: A study of seven cases. Neurology 1993;43:1329-34. 13.Deus-Silva L, Queiroz LS, Zanardi VA, Ghizoni E, Pereira HC, Malveira GLS, et al. Hypertrophic pachymeningitis. Case report. Arq Neuropsiquiatr 2003;61:107-11.

http://dx.doi.org/10.1590/S0004-282X2003000100021

14.Tamura N, Matsudaira R, Hirashima M, Ikeda M, Tajima M, Nawata M, et al. Two Cases of Refractory Wegener's Granulomatosis Successfully Treated with Rituximab. Intern Med. 2007;46:409-14.

http://dx.doi.org/10.2169/internalmedicine.46.6156 